\title{
CERTAIN EFFECTS OF AGITATION UPON THE RELEASE OF PHOSPHATE FROM MUD
}

\author{
By William Stephenson, Ph.D. \\ Dove Marine Laboratory, University of Durham, \\ Cullercoats, Northumberland*
}

\section{INTRODUCTION}

Studies of the phosphate concentration of sea water are of primary importance in assessing the potential productivity of the sea (Sverdrup, Johnson \& Fleming, I942; Harvey, 1945). Amongst the factors governing these concentrations, the role of the bottom deposits has been largely neglected. There is an impression (Marshall, 1947) based upon analyses of marine muds by Moore (1930) and estuarine deposits by Stockfisch \& Benade (I930), that the surface layers of bottom deposits contain large amounts of phosphate. If so, the factors controlling the exchange of phosphate between mud and sea water are of interest. This investigation concerns one of these factors, and later papers will deal with others.

The work has been carried out in the laboratory because, although conditions are artificial, they are relatively controllable, and it is easier to distinguish the significant factors. Estuarine muds have been used in preference to offshore deposits because of their accessibility and because they are more likely to withstand laboratory conditions without catastrophic biological change. Analyses were made throughout upon sea water in contact with mud, thereby avoiding the difficulties of determinations upon mud itself.

\section{METHODS}

Phosphate determinations. Atkins's (1923) modification of Denigès method was used, employing Atkins's original reagents. Molybdate solution (I ml.) and two drops of stannous chloride solution were used per $100 \mathrm{ml}$. sample, and colours compared visually using Hehner or Nessler tubes. Comparisons were initially made in daylight, but it was suspected that variations in spectral composition were altering the salt errors (Cooper, I938) and so all results below were determined in artificial light in a dark room. Tubes were viewed with standards alternatively right and left of the unknown (Matthews, I9I6) and each time a value just above and just below the 'true' value was recorded. Finally the mean of the four values was noted. Salt errors were determined as described by Ibañez (I933), and the factor varied between I.33 and I.37 for

* Now at Dept. of Zoology, University of Queensland, Brisbane. 
sea water, and between I. I5 and I. I8 for samples diluted with an equal volume of distilled water. Reagent blanks were determined as described by Cooper (1933) and allowances were made for salt errors in these blanks. Harvey (1948) has shown, in a paper published since this work was completed, that with stored reagents, blanks are largely due to silicomolybdate formation, and are not subject to salt errors. The results are thus too low by amounts up to about $2 \mathrm{mg} . \mathrm{P}_{2} \mathrm{O}_{5} / \mathrm{m}$. ${ }^{3}$. The experimental error is estimated at about $\pm 2 \mathrm{mg}$. $/ \mathrm{m} .{ }^{3}$, and any arsenate present is included as phosphate (Atkins \& Wilson, I927).

$M u d$. A scraping of the top centimetre of mud, containing Corophium, was collected on II December I 946 from mid-tide level on the south bank of the River Blyth, close to the Fever Hospital. Sand and grit were removed by washing, and sea water, mud, silt, and Corophium were added to a greenish glass tank $(35 \times 27 \times 35 \mathrm{~cm}$. $)$ in a shaded corner of the laboratory. The solids settled as a loose brown layer about $7 \mathrm{~mm}$. thick, and were kept for about a month before the experiments started.

Filtration. With turbid liquids, filtration was essential. Whatman No. 542 papers were used and the first $20 \mathrm{ml}$. of filtrate discarded. Distilled water, sodium chloride solution, and dilute sodium bicarbonate solution extracted no phosphate from these papers or from the glassware.

$\mathrm{pH}$ determinations were performed colorimetrically, and the results, after correction for salt errors, are accurate to about the nearest 0.05 .

\section{RESULTS}

\section{Preliminary experiments}

Sea water in contact with settled mud was analysed. After stirring for 5 min., samples were pipetted at intervals from the middle of the water column, filtered, and analysed. Typical results are given in Table I, and these show, first,

TABLE I

8/9 January I947; $\mathrm{P}_{2} \mathrm{O}_{5}$ at $23.00 \mathrm{hr}$. G.M.T., I25 mg./m. ${ }^{3}$; stirred $23.15-23.20 \mathrm{hr}$.

\begin{tabular}{|c|c|c|}
\hline $\begin{array}{l}\text { Interval between } \\
\text { stirring and } \\
\text { collection of sample } \\
\text { (min.) }\end{array}$ & $\begin{array}{l}\text { Duration of } \\
\text { filtration } \\
\text { (min.) }\end{array}$ & $\frac{\mathrm{P}_{2} \mathrm{O}_{5}}{\left(\mathrm{mg} . / \mathrm{m} .^{3}\right)}$ \\
\hline$\stackrel{0}{0}$ & I5 & III \\
\hline 75 & I5 & IIO \\
\hline 120 & 10 & 120 \\
\hline I95 & I5 & I 22 \\
\hline 240 & I5 & 109 \\
\hline 265 & I5 & I23 \\
\hline 460 & I5 & II 2 \\
\hline
\end{tabular}

considerable variation in phosphate concentration, and secondly that this concentration has decreased. Later experiments gave both increases (Table III) and decreases (Table II) in concentration. 


\section{Ultrafiltration}

In the above experiment only the original sample was unfiltered, and particulate or colloidal material may have increased its phosphate concentration. To evaluate the significance of a colloidal fraction, sea water and mud were stirred, then filtered, and then ultrafiltered through a collodion membrane. After ultrafiltration the phosphate should be reduced by an amount equivalent to that released from the colloids.

Collodion ultrafilters were prepared round a $2.5 \mathrm{~cm}$. boiling tube from the following mixture: $7 \cdot 0 \mathrm{~g}$. dry pyroxylin, I00 ml. absolute alcohol, $100 \mathrm{ml}$. ether, $4.8 \mathrm{~g}$. ethylene glycol. A first coat was applied at $20^{\circ} \mathrm{C}$. and dried for approximately $3 \mathrm{~min}$., and a second similar coat added. A third coat was allowed to dry at $20^{\circ} \mathrm{C}$. for about Io min., and then at $15^{\circ} \mathrm{C}$. for about $2 \frac{1}{2} \mathrm{hr}$. The membrane was removed from the tube after standing in water for $\mathrm{I} \mathrm{hr}$. Many membranes were made similarly, but mostly burst under high pressures. Those finally selected withstood a pressure of $600 \mathrm{~mm}$. $\mathrm{Hg}$ and filtered Congo Red from aqueous solution. During ultrafiltration, a pressure of $500-550 \mathrm{~mm}$. $\mathrm{Hg}$ was used.

Sea water and mud were stirred, and two samples collected, one for normal filtration, and the second for normal filtration followed by ultrafiltration. Analyses showed (see Table II) that the ultrafiltered samples gave the greater phosphate concentrations. These increases were not due to evaporation of water, as chlorinities increased only by $0.5 \%$ during ultrafiltration.

\section{TABLE II}

9/10 January I947; $\mathrm{P}_{2} \mathrm{O}_{5}$ at $23.00 \mathrm{hr}$. G.M.T., on unfiltered unstirred sea water, $\mathrm{I} 23 \mathrm{mg} . / \mathrm{m} .{ }^{3}$; stirred 23.15-23.20 hr.

\begin{tabular}{|c|c|c|c|c|}
\hline $\begin{array}{l}\text { Interval between } \\
\text { stirring and } \\
\text { collection of sample } \\
\text { (min.) }\end{array}$ & $\begin{array}{l}\text { Duration } \\
\text { filtration } \\
\text { (min.) }\end{array}$ & $\begin{array}{c}\mathrm{P}_{2} \mathrm{O}_{5} \\
\left(\mathrm{mg} . / \mathrm{m}^{3}\right)\end{array}$ & $\begin{array}{l}\text { Duration } \\
\text { ultrafiltration } \\
\text { (min.) }\end{array}$ & $\begin{array}{c}\mathrm{P}_{2} \mathrm{O}_{5} \\
\left(\mathrm{mg} . / \mathrm{m}^{3}\right)\end{array}$ \\
\hline 0 & I5 & II5 & - & - \\
\hline 0 & 40 & - & 125 & I49 \\
\hline 2 & IO & I 20 & - & - \\
\hline 2 & 35 & - & I39 & I 45 \\
\hline
\end{tabular}

In the next experiment, sea water was stirred with mud, filtered, and analysed. Half the filtrate was ultrafiltered, and the remainder left standing in a covered beaker for the duration of ultrafiltration. The results (Table III) confirm the increase in phosphate on ultrafiltration, and show that when filtered samples stand in glassware, a marked reduction in phosphate concentration may occur. The anomalous effects of ultrafiltration might be complicated by changes on storage, and these were therefore investigated. 


\section{TABLE III}

IO/II January I947; $\mathrm{P}_{2} \mathrm{O}_{5}$ at $23.00 \mathrm{hr}$. G.M.T., II $8 \mathrm{mg} . / \mathrm{m}^{3}$; stirred $23.15-23.20 \mathrm{hr}$.

$\begin{array}{cc}\begin{array}{c}\text { Interval between } \\ \text { stirring and } \\ \begin{array}{c}\text { collection of sample } \\ \text { (min.) }\end{array}\end{array} & \begin{array}{c}\text { Duration } \\ \text { filtration etc. } \\ \text { (min.) }\end{array} \\ 0 & \begin{array}{c}45 \\ \text { as last, stood } \\ \text { for } 420 \mathrm{~min} . \\ \text { Io5 } \\ \text { as last, stood } \\ \text { for I80 min. }\end{array}\end{array}$

$\mathrm{P}_{2} \mathrm{O}_{5}$
(mg./m..$\left.^{3}\right)$
$\mathrm{I}_{50}$
$\mathrm{I} 38$
$\mathrm{I} 45$
$\mathrm{I} 26$

$\begin{array}{cc}\begin{array}{c}\text { Duration } \\ \text { ultrafiltration } \\ \text { (min.) }\end{array} & \begin{array}{c}\mathrm{P}_{2} \mathrm{O}_{5} \\ \left(\mathrm{mg} \cdot / \mathrm{m}^{3}\right)\end{array} \\ 420 & \mathrm{I} 55 \\ - & - \\ \mathrm{I} 80 & \mathrm{I} 75 \\ - & -\end{array}$

Phosphate Changes in Stored Filtrates of Muddy Sea Water

General Nature of Changes and Effects of Bactericidal Agents

A litre of filtrate was analysed, and three samples of $250 \mathrm{ml}$. set aside in $350 \mathrm{ml}$. conical flasks. One was kept as control, while to the others were added I ml. of $40 \%$ formaldehyde and I ml. of chloroform respectively. Analyses were performed at intervals, and the results (Table IV) show that storage in glassware produces an increase in phosphate concentration, followed by a decrease to the original value or even lower. These changes are prevented by formalin or chloroform.

\section{TABLE IV}

I5/I6 January I947; stirred 2I.30 hr. G.M.T.; filtered 2I.35-02.I5 hr.; $\mathrm{P}_{2} \mathrm{O}_{5}$ of filtrate then II I mg./m. ${ }^{3}$; bottles below filled $02.20 \mathrm{hr}$.

\begin{tabular}{|c|c|c|c|}
\hline \multirow{2}{*}{$\begin{array}{l}\text { Time from } \\
\text { filling bottle } \\
\text { (min.) }\end{array}$} & \multicolumn{3}{|c|}{$\mathrm{P}_{2} \mathrm{O}_{5}\left(\mathrm{mg} . / \mathrm{m}^{3}{ }^{3}\right)$} \\
\hline & Control & I/250 formalin & I $/ 250$ chloroform \\
\hline $\begin{array}{r}40 \\
100\end{array}$ & $\begin{array}{l}\text { II7 } \\
\text { I27 }\end{array}$ & $\begin{array}{l}\text { I09 } \\
\text { III }\end{array}$ & $\begin{array}{l}\text { III } \\
\text { IO9 }\end{array}$ \\
\hline 160 & $\mathrm{I} 22$ & 108 & I09 \\
\hline 220 & II 5 & 108 & 109 \\
\hline 280 & 108 & 109 & IIO \\
\hline
\end{tabular}

Similar results were obtained in an experiment of longer duration using $500 \mathrm{ml}$. samples in I l. bottles (Table V). These results confirm the increase in phosphate concentration, and also show that on prolonged standing the phosphate concentration decreases to below the original value. It should be noted that while the results given in Tables IV and V are similar, the changes are less marked in the latter. Further experiments confirmed both the initial increase and subsequent decrease, for example in one experiment phosphates increased from III to I $44 \mathrm{mg} . / \mathrm{m} .^{3}$ on standing for an hour, and in another they decreased from 100 to $2 \mathrm{mg}$. $/ \mathrm{m}^{3}$ on standing for $\mathrm{I} 8 \mathrm{hr}$. The results in Table $\mathrm{V}$ also confirm that both formalin and chloroform prevent both the increase and decrease in values, and further work showed that a I/250 concentration of toluene had a similar effect. 


\section{TABLE V}

I7 January I947; stirred 09.30 hr. G.M.T.; filtered 09.30-IO.Io hr.; $\mathrm{P}_{2} \mathrm{O}_{5}$ of filtrate then $97 \mathrm{mg} . / \mathrm{m}^{3}$; bottles filled $10.30 \mathrm{hr}$.

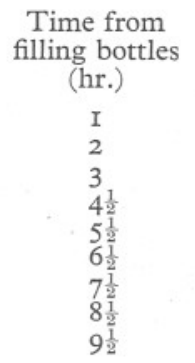

\begin{tabular}{ccc}
\multicolumn{3}{c}{} \\
Control & $\mathrm{I} / 250$ formalin & $\mathrm{I} / 250$ chloroform \\
I04 & 98 & 97 \\
IOI & 98 & 99 \\
IOI & 99 & 98 \\
98 & 97 & 98 \\
98 & 96 & 95 \\
90 & 96 & 96 \\
86 & 95 & 95 \\
84 & 95 & 96 \\
84 & 94 & 95
\end{tabular}

The increase in concentration probably explains the high values after ultrafiltration because this process takes about the same time as the attainment of maximum values on standing. Rise and fall are prevented by bactericidal agents, and this suggests that living organisms in the filtered samples are responsible.

\section{Changes in the Physico-Chemical Environment}

Both rise and fall in phosphate concentration can occur during night or day, and when temperatures are either rising or falling (within the range II $\cdot 0-I 7.5^{\circ} \mathrm{C}$.). The phenomena are not independent of temperature, since the fall at least is greatly retarded by low temperatures. For example, an original phosphate concentration of $105 \mathrm{mg} . / \mathrm{m} .^{3}$ immediately after filtration was reduced after $\mathrm{Ig} \mathrm{hr}$. at $\mathrm{I} 3-\mathrm{I} 4^{\circ} \mathrm{C}$. to $2 \mathrm{mg}$. $/ \mathrm{m}^{3}$, but a parallel sample at $0^{\circ} \mathrm{C}$. was only reduced to $87 \mathrm{mg} . / \mathrm{m}^{3}$.

The phosphate increase on storage is accompanied by a small increase in $\mathrm{pH}$, but the subsequent decrease occurs without further $\mathrm{pH}$ change (Table VI).

\section{TABLE VI}

I7 January I947; stirred 09.30 hr. G.M.T.; filtration 09.30-II.IO hr.; solution stored in Winchester.

$\begin{array}{ccc}\begin{array}{c}\text { Time elapsed } \\ \begin{array}{c}\text { after filtration } \\ \text { (min.) }\end{array}\end{array} & \begin{array}{c}\mathrm{P}_{2} \mathrm{O}_{5} \\ \text { (mg./m. }\end{array} & \\ \text { I0 } & 9 \mathrm{I} & \mathrm{pH} \\ 70 & \text { II8 } & 7 \cdot 4 \\ \text { 130 } & \text { I09 } & 7 \cdot 5 \\ \text { 190 } & \text { I09 } & 7 \cdot 65 \\ 250 & \text { I08 } & 7 \cdot 6 \\ 310 & 108 & 7 \cdot 6 \\ 370 & \text { I07 } & 7 \cdot 6\end{array}$

A filtrate of muddy sea water was poured into bottles, hydrochloric acid or sodium bicarbonate solution added, and the whole thoroughly shaken. (The 
acid and bicarbonate contained negligible quantities of phosphate.) The results of a short experiment (Table VII) show that increasing the $\mathrm{pH}$ augments the rise in phosphate, while decreasing it has virtually no effect.

\section{TABLE VII}

20 January I947; stirred 10.50-10.55 hr. G.M.T.; filtration I0.55-I2.IO hr.

\begin{tabular}{|c|c|c|c|c|c|c|c|c|}
\hline \multirow{2}{*}{$\begin{array}{l}\text { Interval between } \\
\text { filtration and } \\
\text { collection of sample } \\
\text { (min.) }\end{array}$} & \multicolumn{2}{|c|}{ Alkaline } & \multicolumn{2}{|c|}{ Control } & \multicolumn{2}{|c|}{ Acid (I) } & \multicolumn{2}{|c|}{ Acid (2) } \\
\hline & $\begin{array}{c}\mathrm{P}_{2} \mathrm{O}_{5} \\
\left(\mathrm{mg} \cdot / \mathrm{m} .^{3}\right)\end{array}$ & $\mathrm{pH}$ & $\begin{array}{c}\mathrm{P}_{2} \mathrm{O}_{5} \\
\left(\mathrm{mg} . / \mathrm{m}^{3}\right)\end{array}$ & $\mathrm{pH}$ & $\begin{array}{c}\mathrm{P}_{2} \mathrm{O}_{5} \\
\left(\mathrm{mg} \cdot / \mathrm{m}^{3}\right)\end{array}$ & $\mathrm{pH}$ & $\begin{array}{c}\mathrm{P}_{2} \mathrm{O}_{5} \\
\left(\mathrm{mg} \cdot / \mathrm{m} \cdot{ }^{3}\right)\end{array}$ & $\mathrm{pH}$ \\
\hline 5 & 一 & - & I2I & $7 \cdot 4$ & - & - & - & - \\
\hline IO & - & $8 \cdot 8$ & - & & - & $6 \cdot 6$ & - & \\
\hline I IO & I4I & $8 \cdot 8$ & 126 & & 128 & $6 \cdot 7$ & 129 & $6 \cdot 5$ \\
\hline
\end{tabular}

For longer experiments, considerable volumes of filtrates are needed, and filtration takes so long that most of the rise in phosphate concentration has passed. When filtered samples are stored overnight, however, and the phosphate accordingly reduced, this can be regenerated by shaking. Vessels half full of liquid were shaken by hand for $5 \mathrm{~min}$., and the subsequent changes in phosphate concentration were exactly similar to those observed after filtration (see control sample, Table VIII). This is of great interest, and suggests that the normal initial rise in phosphate may be due to mechanical agitation of the mud and sea water.

Further work upon the effect of $\mathrm{pH}$ was performed upon the changes occurring when filtered stored sea water is reshaken by hand for $5 \mathrm{~min}$. Results are given in Table VIII, and these, in addition to demonstrating the effects of agitation, show that: (a) increases in $\mathrm{pH}$ augment the initial phosphate rise, but decreases have only a very slight effect; $(b) \mathrm{pH}$ changes have little effect on the subsequent fall in phosphate concentration.

\section{TABLE VIII}

20 January I947; stirred I0.50-I0.55 hr. G.M.T.; filtered I4.30-I8.00 hr.; stored overnight at $8^{\circ}$ C. At 09.35 hr. 2 I January, $\mathrm{P}_{2} \mathrm{O}_{5}, 98 \mathrm{mg} . / \mathrm{m} .^{3}$. At $09.40 \mathrm{hr}$. poured into flasks, acid and alkali added except to control; all shaken till $09.45 \mathrm{hr}$.

\begin{tabular}{|c|c|c|c|c|c|c|c|c|}
\hline \multirow{2}{*}{$\begin{array}{l}\text { Interval between } \\
\text { shaking and } \\
\text { collection of sample } \\
\text { (min.) }\end{array}$} & \multicolumn{2}{|c|}{ Alkaline } & \multicolumn{2}{|c|}{ Control } & \multicolumn{2}{|c|}{ Acid (I) } & \multicolumn{2}{|c|}{ Acid (2) } \\
\hline & $\begin{array}{c}\mathrm{P}_{2} \mathrm{O}_{5} \\
\left(\mathrm{mg} \cdot / \mathrm{m} .^{3}\right)\end{array}$ & $\mathrm{pH}$ & $\begin{array}{c}\mathrm{P}_{2} \mathrm{O}_{5} \\
\left(\mathrm{mg} \cdot / \mathrm{m} \cdot{ }^{3}\right)\end{array}$ & $\mathrm{pH}$ & $\begin{array}{c}\mathrm{P}_{2} \mathrm{O}_{5} \\
\left.\text { (mg. } / \mathrm{m}^{3}\right)\end{array}$ & $\mathrm{pH}$ & $\begin{array}{c}\mathrm{P}_{2} \mathrm{O}_{5} \\
\left(\mathrm{mg} . / \mathrm{m}^{3}\right)\end{array}$ & $\mathrm{pH}$ \\
\hline 5 & - & $9 \cdot I$ & - & 7.9 & - & $6 \cdot 8$ & - & $6 \cdot 2$ \\
\hline 65 & I25 & 9.01 & 102 & 7.9 & 103 & $6 \cdot 8$ & 103 & $6 \cdot 2$ \\
\hline I25 & I48 & $9 \cdot \mathrm{I}$ & II 5 & $7 \cdot 9$ & I2O & $6 \cdot 8$ & I 25 & $6 \cdot 2$ \\
\hline I85 & II9 & 9.05 & 104 & 7.9 & II6 & $6 \cdot 9$ & I25 & $6 \cdot 3$ \\
\hline 305 & I03 & 9.05 & 78 & $7 \cdot 8$ & IOO & $6 \cdot 9$ & IO2 & $6 \cdot 3$ \\
\hline 365 & 94 & 9.05 & 70 & $7 \cdot 8$ & 85 & 6.9 & 88 & $6 \cdot 25$ \\
\hline \multicolumn{9}{|c|}{ After $385 \mathrm{~min}$. (at I6.Io hr. G.M.T.) all shaken for $15 \mathrm{~min}$. } \\
\hline $\begin{array}{l}25 \\
85\end{array}$ & $\begin{array}{l}\text { II9 } \\
\text { I05 }\end{array}$ & $\begin{array}{l}9.05 \\
9.05\end{array}$ & $\begin{array}{l}89 \\
74\end{array}$ & $\begin{array}{l}7 \cdot 85 \\
7 \cdot 8\end{array}$ & $\begin{array}{l}95 \\
89\end{array}$ & $\begin{array}{l}6.9 \\
6.9\end{array}$ & $\begin{array}{r}87 \\
104\end{array}$ & $\begin{array}{l}6 \cdot 3 \\
6 \cdot 2\end{array}$ \\
\hline
\end{tabular}




\section{Size of the Containing Vessel}

At various times, different-sized bottles of different types of glass were used for storage. The changes were similar for all types, but seemed greater with small vessels. (Compare, for example, the results in Tables IV and VI.) The effect of the size of the bottle was therefore investigated, using bottles of similar shape, and made of similar (white) glass. The results (Table IX) show that both rise and fall in phosphate values are greater in smaller vessels.

\section{Recovery of Phosphate after Disappearance on Long Standing}

After standing overnight at $14^{\circ} \mathrm{C}$. the phosphate concentration of a filtered sample of muddy sea water was reduced from 105 to $2 \mathrm{mg} . / \mathrm{m} .{ }^{3}$. About onethird of the phosphate which had disappeared was recovered from the containing vessel after treatment with distilled water on a water-bath for $\mathrm{I} \frac{1}{2} \mathrm{hr}$. None was obtained from the liquid after boiling for $\mathrm{I} \frac{1}{2} \mathrm{hr}$.

\section{TABLE IX}

4 January I947; stirred 09.20-09.25 hr. G.M.T.; filtered 09.25-II.IO hr. At II.40 hr. $\mathrm{P}_{2} \mathrm{O}_{5}$, $97 \mathrm{mg} . / \mathrm{m}^{3}$. At II.45 hr. all bottles filled to depth of $7 \mathrm{~cm}$. and shaken vigorously till II.5O hr.

Interval between filling $\mathrm{P}_{2} \mathrm{O}_{5}$ in $\mathrm{mg} . / \mathrm{m} .{ }^{3}$ in bottles of different sizes (diameter, cm.)

bottle and collection of sample (hr.)

\begin{tabular}{cccc}
\hline 5.6 & Area in contact with liquid $\left(\mathrm{cm} .{ }^{2}\right)$ & $9 \cdot 7$ \\
\hline c. I48 & c. I96 & c. 226 & c. 291 \\
I07 & IOI & 99 & 97 \\
I05 & 102 & 98 & 98 \\
IO0 & IO0 & 96 & 94 \\
75 & 81 & 92 & 92
\end{tabular}

\section{Discussion}

Preliminary experiments on the effect of agitation upon the exchange of phosphate between estuarine mud and sea water gave variable results. Sometimes phosphate was evolved, and sometimes absorbed by the mud. It was suspected that colloidal material in the samples was introducing complications, and that removal of colloids would reduce the apparent amounts of inorganic phosphate present. On the contrary, removing the colloids was accompanied by an increase in phosphate concentration.

A similar increase occurs, however, when filtered sea water stands in glassware for the duration of ultrafiltration, and this obscures any possible effects of colloids. The increase is not due to phosphate leaching from the glassware, and implies the conversion of a precursor into 'Denigès active phosphate'. This process is more obvious in small containing vessels, which is reminiscent of the effects of size of the containing vessel upon the growth of bacterial populations in stored sea water (ZoBell \& Anderson, 1936; Lloyd, I937; ZoBell, I946, p. 83). It is also prevented by bactericides. Redfield, Smith \& Ketchum (I937) have shown that bacteria will pass extremely fine filters, and 
Dr H. W. Harvey also informs me (personal communication) that cells up to $3 \mu$ in diameter can pass the filters here employed. It appears, therefore, that the above liberation of phosphate is due to the activity of living organisms, but work at present in progress shows that large quantities of phosphate can be freed from animal tissues solely as a result of enzymes in the tissues themselves.

On more prolonged storage, phosphate disappears from solution, and is probably mainly immobilized on the walls of the containing vessel. This removal is slowed by cold and bactericides, and depends on the size of the vessel. This suggests that living organisms are also responsible for the removal of phosphate. After this removal, phosphate can be regenerated by shaking the vessel, and if the previous reduction in concentration is due to removal by bacteria, regeneration is likely to be due to destruction of bacteria, and release of phosphorus-containing compounds.

The similarity between the phosphate release on shaking a filtrate and the initial release when muddy water is filtered suggests that, in the latter process, phosphate is also derived from the protoplasm of destroyed organisms. It is impossible to say whether these are destroyed by the stirring of the mud and water or by the filtration which follows. Probably both processes assist in phosphate release.

Waksman, Stokes \& Butler (1937) and Renn (1937) have shown that phosphate is rapidly regenerated from autolysing bacteria, but as they dealt with large bacterial populations, with different proportions cytolysing at any given time, there is no indication of how long it takes for an individual cell to free its phosphate. Under present conditions this process seems to take about $2 \mathrm{hr}$. to be completed.

The following hypothesis explains the observed facts:

(i) When mud and sea water are mixed by stirring, or when muddy sea water is filtered, or when the filtrates are agitated, bacteria are destroyed.

(ii) Their protoplasm, rich in phosphorus, is broken down by living bacteria, with release of phosphate.

(iii) The bacteria grow, using the remaining organic matter, now poor in phosphorus.

(iv) During growth, they reabsorb the phosphate previously released.

The overall effect is therefore of phosphate absorption by the bacteria. Renn (1937) and Waksman et al. (1937) have already shown that when sea water is incubated in the dark, for the first day or two phosphate is absorbed. Work at present in progress has often given similar results.

This work has been solely concerned with exchange of phosphate between a surface scraping of aerated mud and sea water. Similar results have been obtained with several samples of aerated muds and silts, but there are preliminary indications that oxygen-free muds give different results. 


\section{SUMMARY}

When sea water is stirred with mud and then filtered, its phosphate concentration may either increase or decrease. When the filtrate is ultrafiltered, the concentration increases.

Similar increases occur when the filtrate is stored in glassware, and these obscure any effects of the presence of colloidal material. On storage concentrations rise for about $2 \mathrm{hr}$, , and then fall to as low as $2 \mathrm{mg} \cdot / \mathrm{m}^{3} \mathrm{P}_{2} \mathrm{O}_{5}$ in $\mathrm{I} 8 \mathrm{hr}$.

Rise and fall are both prevented by the addition of formalin, chloroform or toluene, and are more noticeable in small containing vessels. Both occur during either day or night, and when temperatures are either rising or falling.

The increase in phosphate is accompanied by a small increase in $\mathrm{pH}$ and is augmented by an increase in $\mathrm{pH}$ value.

When a filtrate of muddy sea water is kept overnight, and the phosphate concentration reduced, phosphate can be regenerated by shaking.

The phosphate which disappears on long-standing is largely immobilized on the walls of the vessel.

It is suggested that these changes are due to: (i) destruction of organisms by agitation with release of protoplasm; (ii) breakdown of this protoplasm by bacteria with release of phosphate; (iii) absorption of phosphate by bacteria growing on the walls of the vessel.

\section{REFERENCES}

AtKINS, W. R. G., I923. The phosphate content of fresh and salt waters in its relationship to the growth of algal plankton. Fourn. Mar. Biol. Assoc., Vol. 13, pp. I I9-50.

Atrins, W. R. G. \& WILson, E. G., I927. The phosphorus and arsenic compounds of sea water. Fourn. Mar. Biol. Assoc., Vol. I4, pp. 609-I4.

Cooper, L. H. N., I933. Chemical constituents of biological importance in the English Channel. Fourn. Mar. Biol. Assoc., Vol. 18, pp. 677-728.

Cooper, L. H. N., I938. Salt error in the determination of phosphate in sea water. Fourn. Mar. Biol. Assoc., Vol. 23, I7I-8.

Harvey, H. W., I937a. The supply of iron to diatoms. Fourn. Mar. Biol. Assoc., Vol. 22, pp. 205-I9.

Harvey, H. W., I937b. Note on colloidal ferric hydroxide in sea water. Fourn. Mar. Biol. Assoc., Vol. 22, pp. 221-5.

HaRvey, H. W., 1945. Recent Advances in the Chemistry and Biology of Sea Water. Cambridge Univ. Press.

HaRVEY, H. W., I948. The estimation of phosphate and of total phosphorus in sea water. Fourn. Mar. Biol. Assoc., Vol. 27, pp. 337-59.

IBAÑEZ, O. G., I933. Note on the effect of salts in the determination of phosphates in sea water by Denigès method. Fourn. Conseil Int. Explor. Mer, Vol. 8, pp. 326-9.

Lloyd, B., I937. Bacteria in stored sea water. Fourn. Roy. Tech. Coll. Glasgow, Vol. 4, pp. I73-7.

Marshall, S. M., I947. An experiment in marine fish cultivation. III. The plankton of a fertilized Loch. Proc. Roy. Soc. Edinb., B, Vol. 63, pp. 2I-33. 
Matthews, D. J., I9I6. On the amount of phosphoric acid in the sea water off Plymouth Sound, I. Fourn. Mar. Biol. Assoc., Vol. II, pp. I22-30.

Moore, H. B., 1930. The muds of the Clyde Sea area. I. Phosphate and nitrogen contents. Fourn. Mar. Biol. Assoc., Vol. I6, pp. 595-607.

Redfield, A. C., SMITH, H. \& Ketchum, B., I937. The cycle of organic phosphorus in the Gulf of Maine. Biol. Bull. Woods Hole, Vol. 73, pp. 42 I-43.

ReNn, C. E., I937. Bacteria and the phosphorus cycle in the sea. Biol. Bull. Woods Hole, Vol. 72, pp. 190-5.

Stockfisch, K. \& BenAdE, W., I930. Die Charakterisierung der Heilschlamme und verwandter Stoffe-physikalischen Eigenschaften. Mitt. Laborat. preuss. geol. Landesanst., Heft II, pp. 35-83.

Sverdrup, H. U., Johnson, M. W. \& Fleming, R. H., I942. The Oceans. New York. I087 pp.

WAKSMAN, S. A., I933. On the distribution of organic matter in the sea bottom and the chemical nature and origin of marine humus. Soil Sci., Vol. 36, pp. I25-47.

WAKsman, S. A., Stokes, J. L. \& ButLeR, M. R., I937. Relation of bacteria to diatoms in sea water. Fourn. Mar. Biol. Assoc., Vol. 22, pp. 359-72.

ZoBell, C. E., I946. Marine Microbiology. Waltham, Mass. 240 pp.

ZoBell, C. E. \& ANDERSON, D. Q., 1936. Observations on the multiplication of bacteria in different volumes of stored sea water and the influence of oxygen tension and solid surfaces. Biol. Bull. Woods Hole, Vol. 71, pp. 324-42. 